\title{
JUS BELIMBING MANIS (Averrhoa carambola L.) SEBAGAI HEPATOPROTEKTOR PADATIKUS PUTIH (Rattus novergicus strain wistar) YANG DIINDUKSI ANTITUBERKULOSIS RIFAMPISIN DAN ISONIAZID
}

\author{
Antia Devi Iralawati ${ }^{1}$, Diah Hermayanti ${ }^{2}$, Fathiyah Syafitri ${ }^{3}$ \\ Fakultas Kedokteran Universitas Muhammadiyah Malang, J1. Bendungan Sutami No. 188A, Kota Malang, \\ 65145, Indonesia 0341-551149
}

\begin{abstract}
ABSTRAK
Latar Belakang: Rifampisin dan isoniazid merupakan obat yang direkomendasikan dalam pengobatan Tuberkulosis yang memiliki efek samping hepatotoksisitas. Jus belimbing manis diduga mempunyai efek hepatoprotektor karena mengandung flavonoid, tanin, dan vitamin C. Tujuan: Membuktikan efek hepatoprotektor jus belimbing manis terhadap penurunan kadar SGOT, SGPT, dan MDA tikus putih jantan yang diinduksi rifampisin dan isoniazid. Metode: Eksperimental, Post Test Only Control Group Design. Sampel dibagi 5 kelompok perlakuan. Kontrol negatif, kontrol positif diberi rifampisin dan isoniazid masing-masing $200 \mathrm{mg} / \mathrm{KgBB} / \mathrm{hari}$, dan 3 kelompok perlakuan yang diberi rifampisin, isoniazid, dan jus belimbing manis dengan dosis $4 \mathrm{ml} /$ hari, $8 \mathrm{ml} /$ hari, $12 \mathrm{ml} /$ hari selama 14 hari. Data dianalisis dengan uji One-Way ANOVA, uji korelasi, dan uji regresi. Hasil Penelitian dan Diskusi: Analisa statistik dilakukan untuk masing-masing variabel dependent SGOT, SGPT, dan MDA. Uji One-Way ANOVA Sig 0,000<p $(0,05)$ menunjukkan adanya perbedaan yang bermakna antar perlakuan. Uji korelasi Sig $0,000<\mathrm{p}(0,05)$ dengan koefisien sebesar $-0,827$ dan 0,852, dan -0,555 mempunyai korelasi yang sangat kuat, yaitu semakin tinggi dosis jus belimbing manis maka semakin rendah kadar SGOT dan SGPT. Hasil uji regresi menunjukkan jus belimbing manis berpengaruh terhadap penurunan kadar SGOT, SGPT, dan MDA sebesar 68,4\%, 72,6\%, dan 27,9\%. Dosis jus belimbing manis $12 \mathrm{ml} /$ hari merupakan dosis optimal untuk menurunkan kadar SGOT dan SGPT. Kesimpulan: Jus belimbing manis memiliki efek hepatoprotektor terhadap penurunan kadar SGOT, SGPT, dan MDA tikus putih jantan yang diinduksi rifampisin dan isoniazid.
\end{abstract}

Kata Kunci: Jus belimbing manis (Averrboa carambola L.), hepatoprotektor, antituberkulosis

\begin{abstract}
Background : Rifampicin and isoniazid are drug that often recommended for treat tuberculosis and have side effect occurence hepatotoxicity. Star fruit juice has potential in preventing the hepatotoxicity effect because it's contains a lot of flavonoids, tannins, and vitamin C. Objective : This research was aimed to proving the effect of star fruit's juice toward liver decrease levels of SGOT, SGPT, and MDA in white-male albino rats (Rattus novergicus) that induced by rifampicin and isoniazid. Methods : Experimental, Post Test Only Control Group Design. Experimental animals were randomly divided into five group. Negative control group, positive control group was treated with rifampisin dan isoniazid, each $200 \mathrm{mg} / \mathrm{kg} \mathrm{bw} /$ day and 3 treatment groups were treated with rifampicin, isoniazid, and star fruit juice at doses of $4 \mathrm{ml} /$ day, $8 \mathrm{ml} /$ day, and $12 \mathrm{ml} /$ day for 14 days. The data was analized by One Way ANOVA, correlation, and linear regression tests. Results and Discussion : One-Way ANOVA test showed a significant difference between treatments with a Sig 0,000<p $(0,05)$. Correlation coefficient of $-0,827,-0,852$, and $-0,555$ with a Sig 0,000<p(0,05), had a very strong correlation, the higher dose of star fruit juice that was given made lesser SGOT and SGPT level. The results of regression test showed percentage effect of star fruit juice on decreasing SGOT and SGPT level were 68,4\% and 72,6\%, and 27,9\%. Star fruit juice at doses $12 \mathrm{ml} /$ day is the optimal dose for decreasing SGOT and SGPT level. Conclusion : Star fruit juice has the effect of decreasing levels of SGOT, SGPT, and $M D A$ in white-male albino rats (Rattus novergicus) that induced by rifampicin and isoniazid.
\end{abstract}

Key words : Star fruit juice (Averrboa carambola L.), hepatoprotector, antituberculosis drugs

\section{PENDAHULUAN}

Tuberkulosis (TB) di Indonesia masih menempati urutan tertinggi di dunia. Melalui program dunia Millenium Development Goals (MDGs), TB di Indonesia mulai menurun namun masih menempati peringkat kejadian TB ke-5 di dunia (WHO, 2012). Pengendalian TB di Indonesi dilaksanakan dengan menggunakan strategi Directly Observed Treatment Short Course (DOTS) sebagai kerangka dasar dan memperhatikan strategi global untuk mengendalikan TB (Global Stop TB Strategy) (Kemenkes RI, 2014).

Pengendalian TB dengan program DOTS mempergunakan kemoterapi standar jangka pendek selama 6 bulan. Pengobatan TB dengan obat anti tuberkulosis (OAT) primer Rifampisin (RIF) dan isoniazid (INH) sering kali memberikan efek samping yang tidak diinginkan. Kedua obat ini mempunyai potensi untuk menimbulkan 
drug induced hepatitis oleh karena sifatnya yang hepatotoksis. Insiden hepatotoksisitas pemakaian RIF dan INH tanpa dikombinasikan yaitu 1,1\% dan 1,6\% (Chen dan Raymond, 2006; Kumar dan Ramesh, 2014). Sedangkan insiden hepatitis akibat kombinasi isoniazid dan rifampisin meningkat sebesar 2,6\% (Kumar dan Ramesh, 2014). Di RS Dr. Cipto Mangunkusumo insiden hepatitis akibat pemakaian kombinasi RIF dan INH adalah 2,3\% (Amin dan Bahar, 2009).

\section{BELIMBING MANIS (Averrhoa carambola L.)}

Tanaman belimbing manis (Averrhoa carambola L.) banyak terdapat di negara yang beriklim tropis, seperti Malaysia, Taiwan, Thailand, Israel, Florida, Brazil, Filipina, China, Australia, Indonesia, India, dan Bangladesh. Tanaman belimbing manis berbentuk kecil dan menarik, tumbuh lambat dengan batang pohon yang kecil atau berbentuk semak, memiliki banyak batang, tingginya bisa sampai 5$7 \mathrm{~m}$, dan diameter penjalarannya bisa mencapai 20-25 kaki (Dasgupta et al., 2013).

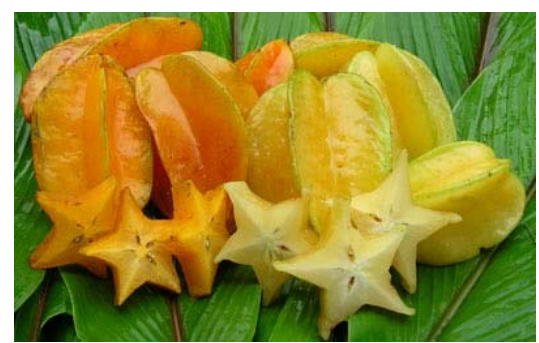

(Dasgupta et al., 2013)

Gambar1. Buah Belimbing Manis Kandungan Nutrisi Belimbing Manis (Averrhoa carambola $L$.)

Belimbing manis merupakan salah satu sumber antioksidan alam yang sangat bagus, seperti vitamin C, ()-epikatekin dan asam galat dalam bentuk gallotanin. Dalam $100 \mathrm{~g}$ buah belimbing manis mengandung air, kalori, protein, lemak, karbohidrat, serat makanan, gula, beberapa senyawa mineral, dan vitamin. Untuk mengetahui lebih jelas mengenai kandungan buah belimbing manis akan dijelaskan pada tabel-tabel di bawah ini (Dasgupta et al., 2013).

Tabel 1. Kandungan Mineral Buah Belimbing Manis dalam 100g

\begin{tabular}{l|c}
\hline \multicolumn{1}{c|}{ Mineral } & Jumlah Kandungan \\
\hline Kalsium (Ca) & $3 \mathrm{mg}$ \\
Besi $(\mathrm{Fe})$ & $0.08 \mathrm{mg}$ \\
Magnesium $(\mathrm{Mg})$ & $10 \mathrm{mg}$ \\
Phosphorus $(\mathrm{P})$ & $12 \mathrm{mg}$ \\
Kalium $(\mathrm{K})$ & $133 \mathrm{mg}$ \\
Natrium $(\mathrm{Na})$ & $2 \mathrm{mg}$ \\
Zinc $(\mathrm{Zn})$ & $0.12 \mathrm{mg}$ \\
Copper $(\mathrm{Cu})$ & $0.137 \mathrm{mg}$ \\
Mangan $(\mathrm{Mn})$ & $0.037 \mathrm{mg}$ \\
\hline
\end{tabular}

(USDA National Nutrient Data Base, 2014)

Tabel 2. Kandungan Asam Amino Buah Belimbing Manis dalam 100g

\begin{tabular}{l|c}
\hline \multicolumn{1}{c|}{ Asam Amino } & Jumlah Kandungan \\
\hline Tryptophan & $8 \mathrm{mg}$ \\
Methionine & $21 \mathrm{mg}$ \\
Lysine & $77 \mathrm{mg}$ \\
\hline
\end{tabular}


Tabel 3. Kandungan Vitamin Buah Belimbing Manis dalam 100g

\begin{tabular}{l|c}
\hline \multicolumn{1}{c|}{ Vitamin } & Jumlah Kandungan \\
\hline Vitamin C & $34.4 \mathrm{mg}$ \\
Thiamine & $0.014 \mathrm{mg}$ \\
Riboflavin & $0.016 \mathrm{mg}$ \\
Niasin & $0.367 \mathrm{mg}$ \\
Folate, DFE & $12 \mu \mathrm{g}$ \\
Vitamin A & $61 \mathrm{IU}$ \\
Vitamin E (alpha-tocophero) & $0.15 \mathrm{mg}$ \\
\hline
\end{tabular}

(USDA National Nutrient Data Base, 2014)

\section{Kandungan Kimia Belimbing Manis (Averrhoa carambola L.)}

Hasil analisis pemeriksaan fitokimia pada buah belimbing manis diketahui mengandung senyawa aktif saponin, alkaloid, flavonoid (proantosianidin, (-)-epikatekin, quercetin-3-o- $\alpha$-dglycoside, rutin, cyaniding-3-o- $\alpha$-dglucoside, cyaniding-3-5-o- $\alpha$-d-diglucoside, â-amirin, dan $\mathrm{C}$ glycoside flavones (apigeni-6-C- $\alpha$-L-fucopyranoside dan apigenin 6$\mathrm{C}-\alpha-1$-fucopyranoside)), tanin, gallotanin, vitamin $\mathrm{C}, \alpha-$ sitosterol, campesterol, lupeol, isofucosterol, asam palmitat, asam oleat, asam lenoleat, kalsium, selulosa, hemiselulosa, mineral, phosphorous, zat besi, pektin, dan karotenoid (Dasgupta et al., 2013).

\section{METODOLOGI}

Penelitian ini merupakan penelitian eksperimental dengan menggunakan metode Post Test Only Control Group Design, menggunakan populasi hewan coba tikus putih jantan (Rattus norvegicus).

\section{Sampel penelitian}

Sampel yang digunakan adalah tikus putih jantan (Rattus norvegicus) strain wistar yang berumur 2-3 bulan dan memiliki berat badan 150-200 gram dengan kondisi sehat. Tikus terbagi menjadi 5 kelompok perlakuan yaitu kelompok kontrol negatif, satu kelompok kontrol positif, dan tiga kelompok perlakuan (tikus yang diberi jus belimbing manis dengan dosis $2 \mathrm{ml} /$ hari, $4 \mathrm{ml} /$ hari, dan $8 \mathrm{ml} /$ hari). Estimasi besar sampel menggunakan 5 ekor tikus pada masing-masing kelompok. (Supranto, 2007). Kelompok 1 : Kontrol negatif (diberi pakan standar); Kelompok 2 :

Kontrol positif (diinduksi rifampisin dan isoniazid); Kelompok 3 : Diinduksi rifampisin dan isoniazid, serta diberi jus belimbing manis $4 \mathrm{ml} /$ hari; Kelompok 4 : Diinduksi rifampisin dan isoniazid, serta diberi jus belimbing manis $8 \mathrm{ml} /$ hari; Kelompok 5: Diinduksi rifampisin dan isoniazid, serta diberi jus belimbing manis $12 \mathrm{ml} /$ hari. Perlakuan selama 14 hari.

\section{Jus belimbing manis (Averrhoa carambola L.)}

Berasal dari buah belimbing manis dari daerah Tulungagung yang di blender tanpa ditambahkan air dengan dosis $4 \mathrm{ml} /$ hari, $8 \mathrm{ml} /$ hari, dan $12 \mathrm{ml} /$ hari yang diberikan 30 menit sebelum induksi rifampisin dan isoniazid selama 14 hari dengan cara sonde modifikasi.

\section{Farmakologi}

a. Rifampisin adalah obat Rifamtibi kaplet 450mg yang diproduksi oleh Sanbe yang dihaluskan dan dilarutkan dalam aquadest dengan dosis $200 \mathrm{mg} / \mathrm{kgBB}$ selama 14 hari melalui sonde modifikasi (Kumar et al., 2010).

b. Isoniazid adalah obat INH Ciba tablet $300 \mathrm{mg}$ yang diproduksi oleh Sandoz yang dihaluskan dan dilarutkan dalam aquadest dengan dosis $200 \mathrm{mg} / \mathrm{kgBB}$ selama 14 hari melalui sonde modifikasi (Kumar et al., 2010).

\section{Pemeriksaan kimiawi}

a. Pemeriksaan kadar SGOT dan SGPT diperiksa dengan metode spektrofotometri (Dufour et al., 2000).

b. Pemeriksaan MDA dilakukan dengan pengukuran kadar MDA pada jaringan hepar dengan reagen TCA-TBA$\mathrm{HCl}$

\section{HASIL PENELITIAN DAN DISKUSI}

\section{Analisis Diskriptif Kadar SGOT, SGPT, dan MDA}

Terdapat perbedaan kadar SGOT, SGPT, dan MDA pada kelompok kontrol positif dan kontrol negatif yang menunjukkan adanya peningkatan dua kali lipat kadar SGOT dan SGPT pada kelompok kontrol positif dibandingkan dengan kadar SGOT dan SGPT pada kelompok kontrol negatif. Kadar SGOT, SGPT, dan MDA tampak menurun pada kelompok yang mendapat jus belimbing manis. 
Tabel 4. Pengaruh Jus Belimbing Manis terhadap Kadar SGOT (mU/ml), SGPT (mU/ml) dan MDA (ng/ml) Hepar Tikus Putih Jantan yang Diinduksi Rifampisin dan Isoniazid

\begin{tabular}{|c|c|c|c|}
\hline Perlakuan & $\begin{array}{c}\text { SGOT (mU/ml) } \\
X=\sum_{\bar{n}} \pm\end{array}$ & $\begin{array}{l}\text { SGPT (mU/ml) } \\
\bar{X}=\frac{\sum x}{n} \pm \text { SD }\end{array}$ & $\begin{array}{l}\text { MDA (ng.ml) } \\
\bar{X}=\frac{\sum x}{n} \pm \text { SD }\end{array}$ \\
\hline Kontrol (+) & $88,39 \pm 4,93$ & $43,16 \pm 2,04$ & $318,5 \pm 10,89$ \\
\hline Kontrol + & $189,64 \pm 5,95$ & $105,08 \pm 4,65$ & $343 \pm 13,74$ \\
\hline PI & $91,40 \pm 4,92$ & $51,40 \pm 5,62$ & $340,5 \pm 5,70$ \\
\hline PII & $90,81 \pm 5,52$ & $48,89 \pm 5,92$ & $308 \pm 7,37$ \\
\hline PIII & $79,05 \pm 4,52$ & $39,26 \pm 6,05$ & $297 \pm 7,20$ \\
\hline
\end{tabular}

(Data Primer yang Diolah, 2014)

Keterangan :

$\mathrm{K}-\quad=$ Kontrol negatif

$\mathrm{K}+=$ Kontrol positif RIF+INH $200 \mathrm{mg} / \mathrm{kgBB} / \mathrm{hari}$

$\mathrm{PI}=$ Perlakuan INH+RIF+ $4 \mathrm{ml} /$ ekor/hari jus belimbing manis

PII = Perlakuan INH+RIF $+8 \mathrm{ml} /$ ekor/hari jus belimbing manis

PIII = Perlakuan INH+RIF $+8 \mathrm{ml} /$ ekor/hari jus belimbing manis

\section{Analisa statistik}

Berdasarkan data yang telah diperoleh, kemudian dilakukan uji normalitas dan homogenitas. Hasil uji normalitas menunjukkan bahwa pada kolom uji ShapiroWilk nilai Sig SGOT yaitu $0,393>\mathrm{p}(0,05)$, SGPT 0,860 $>\mathrm{p}(0,05)$, dan MDA $0,452>\mathrm{p}(0,05)$. Uji homogenitas nilai Sig SGOT yaitu $0,876>\mathrm{p}(0,05)$, SGPT $0,199>\mathrm{p}(0,05)$, dan MDA $0,151>P(0,05)$. Data menunjukkan terdistribusi normal dan homogen.

Uji one-way ANOVA diperoleh nilai Sig SGOT 0,000< $\mathrm{p}(0,05)$, SGPT $0,000<\mathrm{p}(0,05)$, dan MDA $0,000<\mathrm{p}(0,05)$. Hasil statistim one way $A N O V A$ menunjukkan terdapat perbedaan rata-rata kadar SGOT, SGPT, dan MDA tikus putih jantan pada setiap perlakuan. Untuk mengetahui perlakuan mana yang berbeda dilakukan uji tukey.

Berdasarkan hasil lanjut uji tukey (Tukey HSD) diketahui bahwa terdapat perbedaan yang bermakna kadar rata-rata SGOT antara perlakuan kontrol positif $(\mathrm{K}+)$ dengan kontrol negatif ( $\mathrm{K}-), \mathrm{K}+$ dengan $\mathrm{P} 1, \mathrm{~K}+$ dengan $\mathrm{P} 2$, dan $\mathrm{K}+$ dengan P3. Pada kelompok kontrol negatif (K-) hanya memiliki perbedaan rata-rata kadar SGOT yang bermakna terhadap kontrol positif $(\mathrm{K}+)$. Sedangkan pada kelompok perlakuan yang diberi jus belimbing manis, perlakuan P3 memiliki perbedaan yang bermakna kadar rata-rata SGOT antara P3 dengan P1, P3 dengan P2, dan tidak terdapat perbedaan yang bermakna terhadap K-. Hal ini terlihat dari notasi hasil uji tukey pada ketiga perlakuan yang tidak sama.

Pada uji korelasi (Pearson Correlation) didapatkan bahwa nilai Sig (2-tailed) pada SGOT adalah $0,000<\mathrm{p}(0,05)$, yang berarti terdapat hubungan signifikan antara dosis jus belimbing manis dengan kadar SGOT tikus putih jantan. Sedangkan untuk kekuatan korelasi (Pearson Correlation) SGOT yaitu -0,827. Nilai uji korelasi yang negatif pada kadar SGOT mengindikasikan bahwa hubungan yang terbentuk antara dosis pemberian jus belimbing manis dengan kadar SGOT pada tikus putih jantan yang diinduksi rifampisin dan isoniazid berbanding terbalik, artinya semakin besar dosis jus belimbing manis yang diberikan semakin menurun kadar SGOT. Kekuatan pengaruh pemberian jus belimbing manis terhadap penurunan SGOT dikur dengan regresi mendapatkan $R^{2}=0,684$. Persamaan tersebut sesuai dengan tabel Anova Regresi dimana nilai Sig anova regresi $=0,000<\mathrm{p}(0,05)$ yang berarti model regresi cocok secara bermakna. Hal tersebut didukung juga pada tabel uji $t$ table coefficient yang menunjukkan bahwa nilai Sig (constant) = 0,000 dan nilai Sig (dosis) $=0,000$ yang berarti lebih kecil dari nilai $\mathrm{p}(0,05)$. Nilai $\mathrm{R}^{2}$ yang terbentuk pada persamaan tersebut yaitu 0,684 , artinya pengaruh dosis jus belimbing manis terhadap penurunan kadar SGOT adalah sebesar $68,4 \%$. Sedangkan 31,6\% sisanya dipengaruhi oleh faktor lain di luar penelitian ini.

Perbedaan kadar rata-rata SGPT pada kelompok perlakuan berdasarkan hasil lanjut uji tukey (Tukey HSD) diketahui terdapat perbedaan yang bermakna kadar rata-rata SGPT antara perlakuan kontrol positif $(\mathrm{K}+)$ dengan kontrol negatif (K-), $\mathrm{K}+$ dengan $\mathrm{P} 1, \mathrm{~K}+$ dengan $\mathrm{P} 2$, dan $\mathrm{K}+$ dengan P3. Pada kelompok kontrol negatif (K-) hanya memiliki perbedaan rata-rata kadar SGPT yang bermakna terhadap kontrol positif $(\mathrm{K}+)$. Sedangkan pada kelompok perlakuan yang diberi jus belimbing manis, perlakuan P3 memiliki perbedaan yang bermakna kadar rata-rata SGPT antara P3 dengan P1, P3 dengan P2, dan tidak terdapat perbedaan yang bermakna terhadap K-. Hal ini terlihat dari notasi hasil uji tukey pada ketiga perlakuan yang tidak sama.

Pada uji korelasi (Pearson Correlation) didapatkan bahwa nilai Sig (2-tailed) pada SGPT adalah $0,000<\mathrm{p}(0,05)$, yang berarti terdapat hubungan signifikan antara dosis jus belimbing manis dengan kadar SGPT tikus putih jantan. Sedangkan untuk kekuatan korelasi (Pearson Correlation) SGPT yaitu $-0,825$. Nilai uji korelasi yang negatif pada kadar SGPT mengindikasikan bahwa hubungan yang terbentuk antara dosis pemberian jus belimbing manis dengan kadar SGPT pada tikus putih jantan yang diinduksi rifampisin dan isoniazid berbanding terbalik, artinya semakin besar dosis jus belimbing manis yang diberikan semakin menurun kadar SGPT. Besarnya pengaruh diukur dengan persamaan regresi dan mendapatkan nila $\mathrm{R}^{2}=0,726$ 
Persamaan tersebut sesuai dengan tabel Anova Regresi dimana nilai Sig anova regresi $=0,000<\mathrm{p}(0,05)$ yang berarti model regresi cocok secara bermakna. Hal tersebut didukung pula pada uji $t$ table coefficient yang menunjukkan bahwa nilai Sig $($ constant $)=0,000$ dan nilai $\operatorname{Sig}($ dosis $)=0,000$ yang berarti lebih kecil dari nilai $\mathrm{p}(0,05)$. Nilai $\mathrm{R}^{2}$ yang terbentuk pada persamaan tersebut yaitu 0,726 , artinya pengaruh dosis belimbing manis terhadap penurunan kadar SGPT adalah sebesar 72,6\%. Sedangkan 27,4\% sisanya dipengaruhi oleh faktor lain di luar penelitian ini.

Berdasarkan hasil lanjut uji tukey (Tukey HSD) diketahui bahwa terdapat perbedaan yang bermakna kadar rata-rata MDA antara perlakuan kontrol positif $(\mathrm{K}+)$ dengan kontrol negatif (K-), P2 dan P3. Kelompok P1 berbeda bermakna dengan kelompok P2 dan P3, namun tidak berbeda dengan $\mathrm{K}-, \mathrm{K}+$. Kelompok P2 berbeda bermakna dengan $\mathrm{K}+$, dan P1, namun tidak berbeda dengan K- dan P3. Kelompok P3 berbeda bermakna dengan $\mathrm{K}+$ dan $\mathrm{P} 1$, namun tidak berbeda dengan K- dan P2.

Pada uji korelasi (Pearson Correlation) didapatkan bahwa nilai Sig (2-tailed) pada MDA adalah $0,004<\mathrm{p}(0,05)$, yang berarti terdapat hubungan signifikan antara dosis jus belimbing manis dengan kadar MDA tikus putih jantan. Sedangkan untuk kekuatan korelasi (Pearson Correlation) SGOT yaitu -0,555. Nilai uji korelasi yang negatif pada kadar MDA mengindikasikan bahwa hubungan yang terbentuk antara dosis pemberian jus belimbing manis dengan kadar MDA pada tikus putih jantan yang diinduksi rifampisin dan isoniazid berbanding terbalik, artinya semakin besar dosis jus belimbing manis yang diberikan semakin menurun kadar MDA. Besarnya pengaruh diperoleh dengan analisa regresi dengan $\mathrm{R}^{2}$ adjusted $=0,279$. Persamaan tersebut sesuai dengan tabel Anova Regresi dimana nilai Sig anova regresi $=0,004<\mathrm{p}(0,05)$ yang berarti model regresi cocok secara bermakna. Hal tersebut didukung juga pada tabel uji $t$ table coefficient yang menunjukkan bahwa nilai Sig (constant) $=0,000$ dan nilai Sig (dosis) $=0,004$ yang berarti lebih kecil dari nilai $\mathrm{p}(0,05)$. Nilai adjusted $\mathrm{R}^{2}$ yang terbentuk pada persamaan tersebut yaitu 0,279 , artinya pengaruh dosis jus belimbing manis terhadap penurunan kadar MDA adalah sebesar $27,9 \%$. Sedangkan 72,1\% sisanya dipengaruhi oleh faktor lain di luar penelitian ini.

Hasil penelitian di atas sejalan dengan penelitian Kumar et al.(2010), dan Kumar dan Ramesh (2014) yang menyebutkan bahwa pemberian rifampisin dan isoniazid $200 \mathrm{mg} / \mathrm{kgBB} /$ hari selama 28 hari dapat meningkatkan kadar SGOT dan SGPT lebih dari normal yaitu dua kali lipat dari kelompok normal. Kerusakan sel hepar yang terjadi disebabkan oleh metabolit toksik isoniazid (bydrazine) yang dimetabolisme oleh enzim cytochrome P450 terutama isoform CYP3A4 di hepar (Chen dan Raymond, 2006). Produksi bydrazine yang berlebihan membuat kadar cadangan glutathione dengan cepat menurun dan hydrazine akan terakumulasi di dalam hepatosit dan membentuk ikatan kovalen dengan protein hepatosit, menghambat oksidatif, dan terjadi penurunan produksi ATP dalam sel hepar. Akumulasi bydrąine di dalam hepar mengakibatkan peningkatan jumlah produksi radikal bebas (ROS/RNS) yang akan menyebabkan stres oksidatif di hepar (Kumar dan Rames, 2014). Sedangkan rifampisin di dalam hepar akan diubah menjadi 3-formyl rifampicin yang memicu peningkatan reaksi hidrolisis dari isoniazid menjadi bydrazine. Hal ini disebabkan karena rifampisin merupakan aktivator PXR yang memediasi peningkatan ekspresi CYP3A4, sehingga dapat meningkatkan toksisitas dari isoniazid (Ma et al., 2008). Stres oksidatif mengakibatkan kebocoran membran sel hepar yang akan menyebabkan pelepasan enzim transaminase ke dalam sirkulasi, seperti SGOT dan SGPT (Russmann et al., 2009).

Pemberian jus belimbing manis menurunkan kadar SGOT dan SGPT secara signifikan. Hasil ini dapat dilihat pada tikus yang diinduksi rifampisin dan isoniazid, serta diberi jus belimbing manis $12 \mathrm{ml} /$ ekor/hari menunjukkan kadar SGOT dan SGPT yang lebih rendah dibandingkan kelompok yang lain. Hubungan antara dosis pemberian jus belimbing manis terhadap penurunan kadar SGOT dan SGPT tikus putih jantan yang diinduksi rifampisin dan isoniazid berdasarkan analisis uji korelasi menunjukkan korelasi berbanding terbalik dimana semakin besar dosis jus belimbing manis yang diberikan semakin menurunnya kadar SGOT dan SGPT, selain itu nilai 0,827 (SGOT) dan 0,852 (SGPT) menunjukkan bahwa adanya hubungan korelasi yang sangat kuat antara dosis jus belimbing manis dengan penurunan kadar SGOT dan SGPT pada tikus putih jantan (Dahlan, 2011). Persentase pengaruh penurunan kadar SGOT dan SGPT berdasarkan uji regresi yaitu $68,4 \%$ (SGOT) dan $72,6 \%$ (SGPT). Arti dari pengaruh 68,4\% pada SGOT yaitu $68,4 \%$ penurunan kadar SGOT dipengaruhi oleh pemberian jus belimbing dan sisanya 31,6\% dapat dipengaruhi faktor lain yaitu enzim SGOT tidak hanya terdapat di dalam mitokondria sel hepar tetapi enzim SGOT juga terdapat pada sel jantung, otot skeletal, ginjal, dan otak, sehingga apabila terdapat suatu gangguan pada organ tersebut dapat meningkatkan SGOT. Selain itu, pada kerusakan sel hepar yang akut SGPT akan meningkat lebih tinggi daripada SGOT karena kerusakan sel hepar yang terjadi masih di sitoplasma sel hepar dan belum mengenai mitokondria sel hepar. Sedangkan arti dari pengaruh 72,6\% pada SGPT yaitu $72,6 \%$ penurunan kadar SGPT dipengaruhi oleh pemberian jus belimbing manis dan sisanya $27,4 \%$ dapat dipengaruhi oleh faktor lainnya, seperti masih terdapatnya cadangan antioksidan endogen (glutathione) dalam menekan produksi radikal bebas dalam sel hepar.

Hal di atas disebabkan karena semakin besar dosis jus belimbing manis yang diberikan, maka kandungan senyawa aktif dalam belimbing manis semakin tinggi untuk mencegah hepatotoksisitas akibat pemberian rifampisin dan isoniazid. Kandungan senyawa aktif yang diduga memiliki efek hepatoprotektor adalah flavonoid, tanin, dan vitamin C (Dasgupta et al., 2013). Penelitian ini sesuai dengan penelitian sebelumnya yang membuktikan bahwa flavonoid, tanin, dan vitamin C memiliki efek hepatoprotektor dengan bertindak sebagai scavenger radikal bebas, sehingga dapat menurunkan kadar SGOT dan SGPT yang disebabkan karena kebocoran membran sel hepar (Wu et al., 2006; Gül?in et al., 2009; Hassanin et al., 2013). Selain itu, flavonoid memiliki efek hepatoprotektor lain yaitu sebagai inhibitor aktivitas CYP3A, sehingga dapat mempengaruhi farmakokinetik obat (Hidaka et al. 2006). 
Belimbing manis banyak mengandung flavonoid, tanin, dan vitamin C yang berfungsi sebagai antioksidan. Flavonoid memiliki efek hepatoprotektor dengan bertindak sebagai scavenger radikal bebas yang berikatan langsung dengan ROS/RNS dan meningkatkan aktivitas antioksidan endogen, serta sebagai inhibitor aktivitas CYP3A (Wu et al., 2006; Hidaka et al., 2006). Sedangkan tanin dan vitamin C memiliki efek hepatoprotektor dengan bertindak sebagai scavenger radikal bebas yang berikatan langsung dengan radikal bebas ataupun metabolit toksik obat, dan mengatur antioksidan di hepar dengan meningkatkan konsentrasi GSH dan aktivitas GR, serta menurunkan aktivitas catalase, SOD, dan konsentrasi MDA (Gül?in et al., 2009; Hassanin et al., 2013). Selain ketiga senyawa aktif tersebut, ternyata kandungan asam amino methionine dan lysine pada belimbing manis juga memiliki efek hepatoprotektor dengan meningkatkan aktivitas GSH dan menurunkan terbentuknya ROS (Cederbaum, 2010; Thakur et al., 2014). Karena jumlah kandungan kedua asam amino ini di dalam belimbing manis ternyata sangat sedikit, sehingga peneliti tidak menggunakan kedua senyawa ini sebagai efek hepatoprotektor dari buah belimbing manis.

Kadar MDA pada penelitian ini tampak terjadi penurunan pada kelompok perlakuan di banding kelompok kontrol positif, dan terdapat perbedaan yang signifikan pada rerata MDA di masing-masing kelompok sig $0,000<$ $\mathrm{p}(0,05)$ yang artinya terdapat perbedaan rata-rata kadar MDA tikus putih jantan pada setiap perlakuan. Pada uji tukey (Tukey HSD) diketahui bahwa terdapat perbedaan yang bermakna kadar rata-rata MDA antara perlakuan kontrol positif $(\mathrm{K}+)$ dengan kontrol negatif $(\mathrm{K}-)$, P2 dan P3. Kelompok P1 berbeda bermakna dengan kelompok P2 dan P3, namun tidak berbeda dengan $\mathrm{K}-, \mathrm{K}+$. Kelompok P2 berbeda bermakna dengan $\mathrm{K}+$, dan $\mathrm{P} 1$, namun tidak berbeda dengan K- dan P3. Kelompok P3 berbeda bermakna dengan $\mathrm{K}+$ dan $\mathrm{P} 1$, namun tidak berbeda dengan $\mathrm{K}$ - dan P2. Data ini menunjukkan bahwa kelompok perlakuan P2 dan P3 memperlihatkan penurunan kadar MDA yang berbeda bermakna dibandingkan dengan kelompok kontrol positif dan perlakuan P1. Korelasi antara pemberian jus belimbing manis terhadap penurunan kadar MDA menunjukkan kekuatan yang sedang dan berbanding terbalik (pearson correlation -0,555). Namun, penurunan kadar MDA ini hanya $27,9 \%$ disebabkan karena pemberian jus belimbing manis. Selebihnya $72,1 \%$ disebabkan karena faktor lainnya. Kemungkinan dapat disebabkan karena faktor endogen lainnya, atau karena kadar lipid tikus yang normal, oleh karena MDA adalah produk peroksidasi lipid oleh karena adanya stres oksidatif (Güliin et al., 2009; Hassanin et al., 2013).

Penelitian ini dapat menunjukkan jika efek pemberian jus belimbing manis dapat mencegah terjadinya hepatotoksisitas akibat pemberian rifampisin dan isoniazid pada tikus putih jantan dengan adanya penurunan kadar SGOT, SGPT dan MDA. Sehingga dapat diinformasikan kepada masyarakat bahwa jus belimbing manis dapat diminum sebelum pemberian OAT selama pengobatan pada pasien TB. Sedangkan penelitian sebelumnya hanya melihat efek jus belimbing manis dalam menghambat enzim CYP3A4 di hepar dengan melihat konsentrasi carbamazepine yang diberikan pada tikus putih jantan (Hidaka et al. , 2006)

Kesimpulan penelitian ini menunjukkan bahwa pemberian jus belimbing manis dapat mencegah dan melindungi kerusakan hepar akibat pemberian kombinasi OAT Rifampisin dan INH.

\section{DAFTAR PUSTAKA}

Amin Z, Bahar A, 2009, Pengobatan Tuberkulosis Mutakhir dalam Buku Ajar Ilmu Penyakit Dalam Jilid III Edisi V, Internal Publishing, Jakarta, pp.2240-2248.

Amirudin R, 2009, Fisiologi dan Biokimia Hati dalam Buku Ajar Ilmu Penyakit dalam Jilid I Edisi V, Internal Publishing, Jakarta, pp.627-633.

Askgaard DS, Wilcke T, D?ssing M, 1995, Hepatotoxicity Caused by The Combined Action of Isoniazid and Rifampicin, Thorax, Vol.5, pp.213-214.

Cederbaum AI, 2010, Hepatoprotective Effects of S-adenosyl-Lmethionine against Alcohol-and Cytochrome P450 2E1Induced Liver Injury. World Journal of Gastroenterology, Vol.16 No.11, pp.1366-1376

Chen J, Raymond K, 2006, Roles of Rifampicin in Drug-Drug Interactions: Underlying Molecular Mechanisms Involving The Nuclear Pregnane X Receptor, Annals of Clinical Microbiology and Antimicrobial, Vol.5 No.3, pp.1-11.

Correia MA, 2010, Biotransformasi Obat dalam Farmakologi Dasar \& Klinik Bertram G. Katzung Edisi 10, EGC, Jakarta, pp.50-64.

Dahlan MS, 2011, Hipotesis Korelatif dalam Statistik untuk Kedokteran dan Kesehatan Edisi 5, Salemba Medika, Jakarta, pp.167-188

Dasgupta P, Chakraborty P, Bala NN, 2013, Averrhoa Carambola : An Update Review, International Journal of Pharma Research \& Review, Vol.2 No.7, pp.54-63.

Kemenkes RI, 2014, Pedoman Nasional : Pengendalian Tuberkulosis, Jakarta, Kemenkes RI

Dufour DR, Lott JA, Nolte FS, et al., 2000, Diagnosis and Monitoring of Hepatic Injury.II. Recommendations for Use of Laboratory Tests in Screening, Diagnosis, and Monitoring,National Academy of Clinical Biochemistry, Vol.40 No.12, pp.2050-2068.

Gregus Z, Klaasen CD, 2001, Mechanisms of Toxicity in Klassen CD (ed.), Casarret and Doull's Toxicology the Basic Sciences of Poisons 6th edn, Mc Graw Hill, New York.

Guyton AC, Hall JE, 2008, Hati Sebagai Suatu Organ dalam Buku Ajar Fisiologi Kedokteran Guyton \& Hall Edisi 11 editor edisi bahasa Indonesia Luqman YR, Huriawati H, Andita N, Nanda W, EGC, Jakarta, pp.902-908.

Gül?in I, Huyut Z, Elmasta? M, et al., 2010, Radical Scavenging adn Antioxidant Activity of Tannic Acid, Arabian Journal of Chemistry 3, pp.43-53.

Hartanto H, 2002, Tinjauan Klinis Hasil Pemeriksaan Laboratorium (Terjemahan) Edisi 11, EGC, Jakarta, pp.341-371. 
Hassanin KMA, Hashem KS, Abdel-Kawl SH, 2013, Putz R, Pabst R, 2007, Organ Visera Perut Hati dalam Atlas

Hepatoprotective effects of Vitamin $C$ and Micronized Vitamin C Againts Paracetamol Induced Hepatotoxicity in Rats : A Comparative Study, International Journal of Biochemistry and Biotechnology, Vol.2 No.7, pp.474483.

Hidaka M, Fujita K, Ogikubo T, et al., 2004, Potent Inbibition by Star Fruit Of Human Cytochrome P450 3 A (CYP3A) Activity, The American Society for Pharmacology and Experimental Therapeutics, Vol.32 No.6, pp.581-583.

Hidaka M, Okumura M, Kai H, et al., 2006, Transient Inbibition Of CYP3A in Rats by Star Fruit Juice, The American Society for Pharmacology and Experimental Therapeutics, Vol.34 No.3, pp.343-345.

Huang YS, Chern HD, Su WJ, et al., 2002, Polymorphism of the N-Acetyltransferase 2 Gene as a Susceptibility Risk Factor for Antituberculosis Drug-Induced Hepatitis, Hepatology, Vol.35, pp.883-889.

Kalra BS, Aggarwal S, Khurana N, et al., 2007, Effect of Cimetidine on Hepatotoxicity Induced by Isoniazid-Rifampicin Combination in Rabbits, Indian Journal of Gastroenterology, Vol.26, pp. 18-21.

Kamil N, Imran-ul-Haque HS, 2014, Hepatoprotective Effect of Calotropis procera in Isoniazid and Rifampicin Induced Hepatotoxicity, Pharmacognosy Journal, Vol.6 No.5, pp.9-14, viewed 15 Agustus 2014, < http:// www.phcogfirst.com/article/98>.

Kumar GSJ, Krishna BRB, Kumar VG, et al., 2010, Hepatoprotective and Antioxidant Activity of the Alcoholic Extract of Ipomoea Turpetnm against Anti-TB Drugs Induced Hepatotoxicity in Rats, Journal of Advances in Drug Research, Vol.1 Issue.1, pp.10-19.

Kumar PS, Ramesh P, 2014, Evaluation of Hepato Protective Activity of Methanolic Stem Bark Extract of Mangifera indica in Rats, International Journal for Advanced Review and Research in Pharmacy, pp.129-143.

Labbe G, Pessayre D, Fromenty B, 2008, Drug-Induced Liver Injury Through Mitochondrial Dysfunction : Mechanisms and Detection during Preclinical Safety Studies, Fundamental \& Clinical Pharmacology, Blackwell Publishing Ltd, Vol.22, pp.335-353.

Li T, Chiang JYL, 2006, Rifampicin Induction of CYP3A4 Requires PXR Crosstalk with HNF4á and Co-Activators, and Suppression of SHP Gene Expression, Drug Metab Dispos, Vol.34 No.5, pp.756-764.

Ma X, Idle FR, Gonzalez FJ, 2008, The Pregnane X Receptor: From Bench to Beside, Expert Opin Drug Metab Toxicol, Vol.4 No.7, pp.895-908.

Notoatmodjo S, 2005, Metodologi Penelitian Kesehatan, Asdi Mahasatya, Jakarta.

PDPI, 2011, Tuberkulosis. Pedoman Diagnosis dan Penatalaksanaan di Indonesia Revisi Pertama Juli 2011, Perhimpunan Dokter Paru Indonesia, Jakarta, pp.9-19.

Petri WA, 2008, Senyawa Antimikroba (Lanjutan) Obat-obat yang Digunakan pada Kemoterapi Tuberkulosis, Penyakit Kompleks Akibat Mycobacterium avium, dan Lepra dalam Dasar Farmakologi Terapi Goodman \& Gilman Volume 2 Edisi 10, EGC, Jakarta, pp.12461267.
Anatomi Manusia Sobotta Edisi 22 Jilid 2 editor bahasa Indonesia Liliana S, EGC, Jakarta, pp.142-149.

Rodwell VW, 2009, Katabolisme Protein dan Nitrogen Asam Amino dalam Biokimia Harper Robert K. Murray, Daryl K. Granner, Victor W. Rodwell Edisi 27 editor bahasa Indonesia Nanda W, Leo R, Linda D, Liena, Frans D, Luqman YR, EGC, Jakarta, pp. 255-262.

Rita, Rauza Sukma, 2009, Pengaruh Ekstrak Mengkudu Terhadap Kadar Malondialdehid Darah dan Aktivitas Katalase Tikus Diabetes Melitus diinduksi Aloksan, Majalah Kedokteran Andalas, 33(1), p. 56

Russmann S, Kullak-Ublick GA, Grattagliano I, 2009, Current Concepts of Mechanisms in Drug-Induced Hepatotoxicity, Current Medicinal Chemistry, Vol.16 No.23, pp.30413053.

Sadikin M, 2002, Biokimia Enzim, Widya Medika, Jakarta, pp.280-309.

Sherlock S, Dooley J, 2002, Drugs and The Liver in Diseases of Liver and Biliary System 11th ed., Blackwell Scientific Publications, Oxford, pp.322-356.

Singh A, Bhat TK, Sharma OP, 2011, Clinical Biochemistry of Hepatotoxicity, J Clinic Toxicol, pp.1-19.

Supranto J, 2007, Teknik Sampling untuk Survei dan Eksperimen, PT. Rinek Cipta, Jakarta.

Swaroop TVSS, Gowda SKP, 2012, Review Article Hepatotoxicity Mechanisms and Its Biomarkers, International Journal of Pharmaceutical and Chemical Sciences, Vol.1 No.2, pp.675-682.

Tayal V, Bupinder SK, Sarita A, et al., 2007, Hepatoprotective Effect of Tocopherol Againts Isoniazid and Rifampisin Induced Hepatotoxicity in Albino Rabbits, Indian Journal of Experimental Biology, Vol.45, pp.1031-1036.

Tellingen CV, 2003, Organ Physiology from Phenomenological Point of View, LouisBolk Institute, Driebergen (3):4.

Thakur A, Kanduri AB, Saxena MJ, et al., 2014, Comparative Efficacy of Herbal and Synthetic Amino Acids for Growth Performance and Hepatoprotective Action in Broiler Chickens, International Journal of Biomedical and Advance Research, Vol.5 No.1, pp.14-18

Ting-Jun FAN, Li-Hui HAN, Ri-Shan CONG, et al., 2005, Caspase Family Proteases and Apoptosis, Acta Biochimica et Biophysica Sinica, Vol.37 No.11, pp.719-727.

Tostmann A, Martin JB, Rob EA, et al., 2007, Antituberculosis Drug-Induced Hepatotoxicity: Concise up-to-date Review, Journal of Gastroenterology and Hepatology, Vol.23, pp.192202.

USDA National Nutrient Dasa Base, 2014, Full Report (All Nutrients) 09060, Carambola, (star fruit), raw, Agricultural Research Service United States Department of Agriculture, viewed 30 April 2014, <http://ndb.nal.usda.gov/ $\mathrm{ndb} / \mathrm{foods} / \mathrm{show} / 2252$ ? fg $=\& \mathrm{man}=$ \&lfacet $=\&$ count $=\& \mathrm{~m}$ ax $=\&$ sort $=\&$ qlookup $=\&$ offset $=$ $\&$ format $=$ Fu ll\&new $=1 \&$ measureby $>$.

Valko, 2006, Free Radicals and Antioxidants in Normal Physiological Functions and Human Desease, Science Direct, Vol 33 pp,44-48

WHO, 2012, Global Tuberculosis Report 2013, World Health Organization, viewed 05 Februari 2014, <http:// www.who.int/tb/publications/global_report/en/>. 


\section{Volume 8 No 2 Desember 2012}

Wu Y, Wang F, Zheng Q, et al., 2006, Hepatoprotective Effect of Total Flavonoids from Laggera alata Againts Carbon Tetracbloride-Induced Injury in Primary Cultured Neonatal Rat Heepatocytes and in Rats with Hepatic Damage, Journal of Biomedical Science, Vol.13, pp.569-578. 